\title{
Azo Dye Degradation by Phanerochaete chrysosporium in the Medium Enriched with Nitrogen in the Presence of Primary Co-Substrate
}

\author{
Marcus Vinicius Freire Andrade ${ }^{1 *}$, Karla Mayara Lima da Silva ${ }^{2}$, João Paulo da Silva \\ Siqueira $^{2}$, Carlos Ronald Pessoa Wanderley ${ }^{3}$, Rinaldo dos Santos Araújo ${ }^{2}$, Gloria Marinho ${ }^{2}$ \\ and Kelly Rodrigues ${ }^{2}$ \\ ${ }^{I}$ Departamento de Hidráulica e Saneamento; Universidade de São Paulo; São Carlos - SP - Brasil. ${ }^{2}$ Programa de \\ Pós Graduação em Tecnologia e Gestão Ambiental; Instituto Federal do Ceará; Fortaleza - CE - Brasil. \\ ${ }^{3}$ Departamento de Meio Ambiente; Instituto Federal do Ceará; Maracanaú - CE - Brasil
}

\begin{abstract}
This work sought to evaluate the ability of fungi Phanerochaete chryosporium to degrade congo red azo dye in batch reactor, evaluate the influence of glucose and wheat bran as co-substrates on the removal of the dye in the medium and investigate the influence of ammonium chloride, ammonium nitrate and ammonium sulfate as the inorganic nitrogen source for the process. Wheat bran was not effective satisfactorily for the removal of dye and organic matter had no desired effect for the removal of color and organic matter and showed the lowest values of $k_{2}$, $0.008 \mathrm{M}^{-1} \cdot d^{-1}$ and $0.0004 \mathrm{M}^{-1} \cdot d^{-1}$, respectively. Glucose presented the best response with the highest final percentage of dye removal (97\%) and rate of dye removal $\left(0.017 M^{-1} . d^{-1}\right)$, without adding an external source of nitrogen.
\end{abstract}

Key words: Wheat bran, glucose, congo red, fungi, nitrogen

\section{INTRODUCTION}

Nowadays, environmental contamination by organic and inorganic constituents has become a major problem. Many compounds from industrial activities are discharged without treatment, especially in water bodies, making the environment unsuitable for habitation due to their toxic and recalcitrant characteristics (Dellamatrice 2005). Textile industries show high pollutant potential and their wastewaters are considered to be the most hazardous effluents to treat $(\mathrm{Fu}$ and Viraraghavan 2001). According to Dellamatrice (2005), there is also a great concern about the human contamination caused by the inadequate discharge of textile wastewaters in water bodies, mainly to the food chain as these compounds are bioaccumulated by the living organisms. Many compounds discharged with these effluents are mutagenic or carcinogenic and their effects in the organism are not completely known.

Azo dyes are considered the most toxic compound to the aquatic biota and carcinogenic to the human being (Binupriya et al. 2008) due to their breakdown products that form intermediates products such as aromatic amines (Chen et al. 2009). Thus, it is essential to remove these dyes before their release into natural water streams that can modify the ecosystem and/or cause damage to the population health (Zanoni and Alves 2001). Various physical-chemical and biological technologies have been applied to remove the dyes

*Author for correspondence: marcusviniciusan@gmail.com 
from the wastewaters but each one has its technological and economical limitations. Biological treatment has received wide attention as a potential alternative for textile wastewater treatment due to its low costs compared to the majority of physical-chemical methods (Van Der Zee and Villaverde 2005).

Since 1980, white-rot fungi have been used as an alternative to remove the colour of effluents and degrade xenobiotic compounds. These fungi are capable of producing enzymatic complexes that degrade a great variety of compounds (Rodrigues et al. 2003). The mechanism of recalcitrant compounds degradation by white-rot fungi involves enzymes of phenol oxidases group, such as lignin peroxidase (LiP), manganese peroxidase $(\mathrm{MnP})$ and laccases. White-rot fungi are the bestknown dye-decolourizing microorganisms. These organisms also synthesize a number of enzymes, which contribute to the decolorization process through extracellular or intracellular enzymatic pathways (Kamida et al. 2005).The enzymes produced by white-rot fungi are regulated by the depletion of nutrients, mainly nitrogen that has stronger effect to this process. Nitrogen is an essential component to the cells as it is present in their composition and constituents (Ben Hamman 1997; Bitton 2005). Phanerochaete chrysosporium is the most common fungus associated with microbial degradation (Gomma et al. 2008). This fungus has been used, with promising results, in bioremediation processes of textile effluents (Alam et al. 2009), contaminated areas with polycyclic aromatic hydrocarbons (Ding et al. 2008), bleaching Kraft paper effluents (Freitas et al. 2009) and anthracene-contaminated waters (Mohammadia and Nasernejad 2009).

This work sought to evaluate the ability of $P$. chryosporium to degrade congo red azo dye and the effect of co-substrates such as glucose and wheat bran on the removal of this dye and organic matter in batch assays. Also, the effect of the use of sucrose and glucose as co-substrates on the removal of congo red in the presence of different nitrogen sources (ammonium chloride, ammonium sulphate and ammonium nitrate) was evaluated

\section{MATERIAL AND METHODS}

\section{Cultivation of Phanerochaete chrysosporium}

Phanerochaete chrysosporium was cultivated in a growth medium containing (g.L $\left.\mathrm{L}^{-1}\right)$ yeast extract (2.0), glucose 20.0, $\mathrm{K}_{2} \mathrm{HPO}_{4}$ 1.0, $\mathrm{KH}_{2} \mathrm{PO}_{4}$ 0.6, $\mathrm{MgSO}_{4} .7 \mathrm{H}_{2} \mathrm{O} 0.5$ and peptone 2.0 at $30^{\circ} \mathrm{C}$ for $5 \mathrm{~d}$. The spores were removed with Tween 80/isotonic saline solution (1:5) and stored in a sterilized glass flask. The inoculum was transferred to the reactors in the concentration of $2 \times 10^{6}$ spores. $\mathrm{mL}^{-1}$.

\section{Dye}

Congo red $\left(\mathrm{C}_{32} \mathrm{H}_{22} \mathrm{~N}_{6} \mathrm{Na}_{2} \mathrm{O}_{6} \mathrm{~S}_{2}\right)$ (Fig. 1), an azoic and direct dye, with a molecular weight of 696,66 , colour index no. 22120 and spectrum of absorbance of $500 \mathrm{~nm}$ (Binupriya et al. 2008) was used in this study.

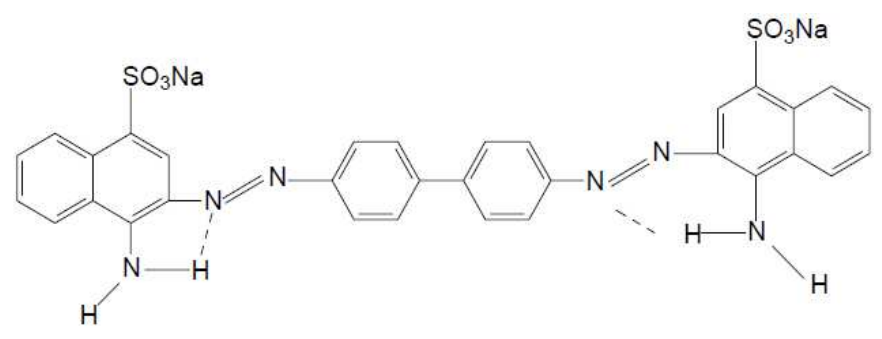

Figure 1 - Chemical structure of Congo red dye.

Influence of the usage of the wheat bran and glucose as co-substrates (Phase I)

Batch studies were carried out in $250 \mathrm{~mL}$ Erlenmeyer's flasks containing $150 \mathrm{~mL}$ of stock basal medium and $2 \times 10^{6}$ spores. $\mathrm{mL}^{-1}$ of fungal inoculum. Wheat bran and glucose were added in the concentration of $1 \%(\mathrm{w} / \mathrm{v})$, and $1 \mathrm{~g} . \mathrm{L}^{-1}$ respectively, and tested together and separately.
The stock basal medium (SBM) consisted of (g.L $\left.\mathrm{L}^{-1}\right): \quad \mathrm{KH}_{2} \mathrm{PO}_{4} \quad 2.0, \quad \mathrm{MgSO}_{4} \cdot 7 \mathrm{H}_{2} \mathrm{O} \quad 0.5$, $\mathrm{CaCl}_{2} \cdot 2 \mathrm{H}_{2} \mathrm{O} \quad 0.1$ and $\left(\mathrm{NH}_{4}\right)_{2} \mathrm{C}_{4} \mathrm{H}_{4} \mathrm{O}_{6}$ 0.2. The medium was supplemented with $30 \mathrm{mg} . \mathrm{L}^{-1}$ of dye and $10 \mathrm{~mL} . \mathrm{L}^{-1}$ of mineral solution. Tap water was used to prepare the medium. The mineral solution (g.L ${ }^{-1}$ ) was composed by $\mathrm{MgSO}_{4} .7 \mathrm{H}_{2} \mathrm{O} 3.0, \mathrm{NaCl}$ 1.0, $\quad \mathrm{MnSO}_{4} \cdot \mathrm{H}_{2} \mathrm{O} \quad 0.5, \quad \mathrm{FeSO}_{4} \cdot 7 \mathrm{H}_{2} \mathrm{O} \quad 0.1$, 
$\mathrm{ZnSO}_{4} \cdot \mathrm{H}_{2} \mathrm{O} \quad 0.1, \quad \mathrm{CoCl}_{2} \cdot 6 \mathrm{H}_{2} \mathrm{O} \quad 0.1, \mathrm{CaCl}_{2} \cdot 2 \mathrm{H}_{2} \mathrm{O}$ $0.082, \mathrm{H}_{3} \mathrm{BO}_{3} 0.01$ and $\mathrm{CuSO}_{4} .5 \mathrm{H}_{2} \mathrm{O}$ 0.01. The $\mathrm{pH}$ of the medium was adjusted to $\mathrm{pH} 5.0$ before being sterilized at $121^{\circ} \mathrm{C}$ for $15 \mathrm{~min}$.

Reactors were operated under different conditions in duplicate: control reactors (CR) - containing only basal medium; reactors with fungi (FR) containing stock basal medium and inoculum; reactors with fungi and glucose (FGR) containing stock basal medium, inoculum and 1 g. $\mathrm{L}^{-1}$ of glucose; reactors with fungi and wheat bran (FBR) - containing stock basal medium, inoculum, $1 \%(\mathrm{w} / \mathrm{v})$ of wheat bran; reactor with fungi, wheat bran and glucose (FBGR) containing stock basal medium, inoculum, glucose $\left(1 \mathrm{~g} . \mathrm{L}^{-1}\right)$ and $1 \%(\mathrm{w} / \mathrm{v})$ of wheat bran. Reactors were agitated on rotary shaker at $30^{\circ} \mathrm{C}$ and 150 rpm for $15 \mathrm{~d}$. Aliquots of $2.0 \mathrm{~mL}$ were withdrawn after $1,3,5,7,10,13$ and $15 \mathrm{~d}$ to determine the efficiency of dye and organic matter removal.

\section{Influence of the inorganic nitrogen source (Phase II)}

Congo red (30 mg. $\left.\mathrm{L}^{-1}\right)$ and the same basal medium of the Phase I was used in duplicate in $250 \mathrm{~mL}$ Erlenmeyer's flasks, with modified nitrogen source, viz. 0.042 g.L $\mathrm{L}^{-1}$ ammonia chloride (RFNI), ammonia sulphate (RFN-II) and ammonia nitrate (RFNIII) with 5 g.L . $^{-1}$ of glucose (Phase I) or saccharose (Phase II). RFSN reactors did not receive nitrogen source. Aliquots of $2.0 \mathrm{~mL}$ were withdrawn after1, 5, 10, 15, 20, 25 and $30 \mathrm{~d}$.

\section{Determined Variables}

Organic matter concentration (COD), $\mathrm{pH}$ and dye concentration were determined in the Phase I; dye concentration, $\mathrm{pH}$ and manganese peroxidase (MnP) enzyme were determined in the Phase II. COD and $\mathrm{pH}$ were determined according to standard APHA procedures (APHA 2005). Dye concentration was measured at the wavelength $(\lambda)$ of $500 \mathrm{~nm}$ by a UV-VIS spectrophotometer (Biospectro - SP 220 - Brazil). A standard curve was obtained for Congo red known concentrations ranging from 0 to $50 \mathrm{mg} / \mathrm{L}$. Before the absorbance measurement, the samples were centrifuged at $3500 \mathrm{rpm}$ for $15 \mathrm{~min}$ to separate out the remnants of fungal biomass and the supernatant was analyzed for $\mathrm{COD}, \mathrm{pH}$, dye concentration and enzyme assays. All the experiments as well as the controls were run in duplicate.

The manganese peroxidase $(\mathrm{MnP})$ activity was determined using the method described by Aguiar
Filho (2008). For this, $50 \mu \mathrm{L}$ of $\mathrm{MnSO}_{4}, 50 \mu \mathrm{L}$ of $\mathrm{H}_{2} \mathrm{O}_{2}$ in succinate buffer, $100 \mu \mathrm{L}$ of sodium lactate, $200 \mu \mathrm{L}$ of bovine albumin and $600 \mu \mathrm{L}$ of supernatant (sample) were taken in each assay tube. An assay tube was sterilized for $10 \mathrm{~min}$ (control) and cooled. The initial time (zero) was determined as the measurement of the absorbance with $100 \mu \mathrm{L}$ of phenol red. After $10 \mathrm{~min}$, the final time was determined with the measurement of the absorbance after the addition of $40 \mu \mathrm{L}$ of $\mathrm{NaOH}$ to the reaction. The samples and controls were measured against zero cross spectrum at $610 \mathrm{~nm}$. The enzymatic activity was obtained from Equation 1.

$$
\mathrm{UI} / \mathrm{L}=\underset{\varepsilon}{\varepsilon} \frac{\Delta \mathrm{abs}}{\mathrm{R} \times \mathrm{t}} \times 10^{6}
$$

Where $\Delta$ abs is the absorbance variation, $\varepsilon$ is the molar absorption coefficient $\left(\varepsilon{ }_{610 \mathrm{~nm}}=44600\right.$ L/M.cm), R is the quantity of the sample solution $(\mathrm{mL})$ and $\mathrm{t}$ is the time of the reaction (min). UI/L is the international unity $(\mu \mathrm{mol} / \mathrm{min})$. Data were analyzed by one-way analysis of variance (ANOVA) with Tukey test to compare results and obtain the statistical parameter. Readings were considered significant when $P$ was $\leq 0.05$.

\section{RESULTS AND DISCUSSION}

\section{Phase I}

The reactors with fungi and wheat bran (FBR) and the reactors with fungi (FR) showed maximum efficiencies of dye removal (88 and $77 \%$, respectively) at the $5^{\text {th }}$ day of operation. At the end of the experiment, however, the addition of $1 \%$ $(\mathrm{w} / \mathrm{v})$ wheat bran as co-substrate did not demonstrate significant differences in the removal efficiencies of the dye by the FBR (76\%) and FR (73\%) reactors. Significance level of $(5.3 \%)$ the experimental data was obtained by Tukey test, indicating that FR and FBR reactors presented removal efficiencies statistically similar $(\mathrm{P}>$ 0.05). This corroborated the fact that the addition of wheat bran as co-substrate did not increase the removal of dye. Dellamatrice et al. (2005) evaluated the removal of colour of industrial effluent by two species of Pleurotus ostreatus, using wheat bran $\left(0.05\right.$ g.mL $\left.\mathrm{mL}^{-1}\right)$ and sugar cane bagasse $\left(0.12\right.$ g. $\left.\mathrm{mL}^{-1}\right)$. After 15 days of operation, the authors observed the complete removal of the dye of the industrial effluent. However, $P$. chrysosporium was able to remove $88 \%$ of the dye 
in a shorter period of time in this study, even with the application of the same co-substrate at the concentration of $1 \%(\mathrm{w} / \mathrm{v})$.

Figure 2 shows the removal of Congo red dye by control reactors (CR), fungi reactors (FR), fungi and wheat bran reactors (FBR), fungi and glucose (FGR) reactors, fungi, wheat bran and glucose reactors (FBGR).

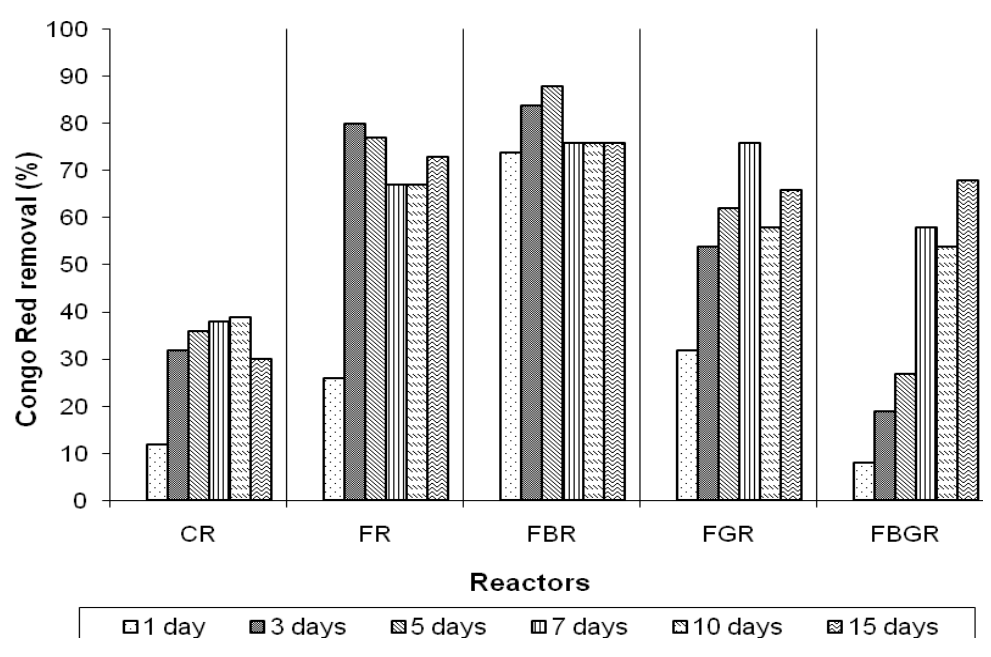

Figure 2 - Performance of the batch reactors in the removal of congo red dye in Phase I.

The removal of the dye by the control reactors (CR) was lower than that observed in the other reactors and equal to $30 \%$ at the $15^{\text {th }}$ day of operation. Reactors with fungi and glucose (FGR) reactors achieved maximum removal of Congo red $(76 \%)$ at the $6^{\text {th }}$ day and $66 \%$ at the $15^{\text {th }}$ day. The same behaviour was noted in the reactors containing fungi, wheat bran and glucose (FBGR) with removal of $68 \%$. Although FGR and FBGR presented similar removal efficiencies of Congo red at the $15^{\text {th }}$ of operation, these values were statistically different $(\mathrm{P}<0.05)$. Chen et al. (2008) reported $98 \%$ removal of Orange $\mathrm{G}$ dye in basal medium by $P$. sordida in the simultaneous presence of 0.95 g.L. $\mathrm{L}^{-1}$ of glucose and 0.5 g.. ${ }^{-1}$ of ethanol as co-substrates in a period of $72 \mathrm{~h}$. In the present work, removal of $58 \%$ of Congo red dye was obtained in the presence of 1.0 g.L. $\mathrm{L}^{-1}$ of glucose as co-substrate. This removal efficiency was lower than that reported by Chen et al. (2008). This could be due to the fact that Congo red had a more complex molecular structure than Orange $G$ with double azoic linkage between the aromatic rings.

Equation 2 shows the velocity of Congo red dye removal adjusted by the kinetic equation of second order. $\frac{1}{c}=\frac{1}{c_{n}}-k_{2} x t$

Where $\mathrm{C}$ is the dye concentration at time $\mathrm{t}, \mathrm{Co}$ is the initial dye concentration, $k_{2}$ is the velocity constant and $\Delta \mathrm{t}$ is the variation of time. Velocity constant $\left(k_{2}\right)$ and correlation coefficient $\left(\mathrm{r}^{2}\right)$ estimated to CR, FR, FBR, FGR and FBGR reactors are tabulated in Table 1.

The values of the velocity constant $\left(k_{2}\right)$ indicated that even with the higher removals of Congo red dye achieved by FR (73\%) and FBR (76\%) reactors, glucose increased 1.8 times this velocity when compared to the reactors with fungi and wheat bran (FBR). The velocity of Congo red dye removal was 1.6 times higher in the reactors in the absence of co-substrate than that obtained in FBR reactors and similar to that obtained in the FGR reactors. The removal efficiencies achieved by FR and FBR reactors were not different statistically ( $\mathrm{P}$ $>0.05)$, corroborating the similarity observed between the velocity constants $\left(k_{2}\right)$ of 12 and 14 $\mathrm{L} \cdot \mathrm{g}^{-1} \cdot \mathrm{d}^{-1}$ of these reactors, respectively. The maximum removal of the organic matter in the medium occurred at the last day of operation and was 99, 80, 93, and 87\% in FR, FBR, FGR and FBGR, with the exception of CR reactors where it was $25 \%$ only (Fig. 3 ). 
Table 1 - Removals of dye in function of the velocity constant $\left(k_{2}\right)$ and correlation coefficient $\left(\mathrm{r}^{2}\right)$ to $\mathrm{CR}, \mathrm{FR}, \mathrm{FBR}$, FGR and FBGR reactors.

\begin{tabular}{ccc}
\hline Reactor & $\boldsymbol{k}_{\mathbf{2}}\left(\mathbf{L} \cdot \mathbf{g}^{-\mathbf{1}} \cdot \mathbf{d}^{\mathbf{1}}\right)$ & $\mathbf{r}^{\mathbf{2}}$ \\
\hline CR & 1.0 & 0.843 \\
FR & 12.0 & 0.896 \\
FBR & 7.7 & 0.704 \\
FGR & 14 & 0.956 \\
FBGR & 7.0 & 0.916 \\
\hline
\end{tabular}

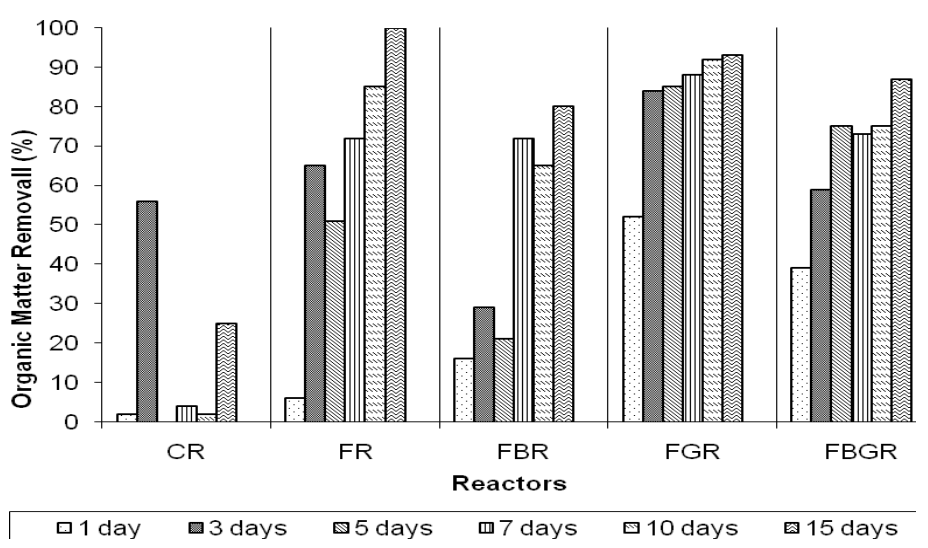

Figure 3 - Performance of the batch reactors in the removal of COD in Phase I.

Guimarães et al. (2005) reported lower COD removal $(48 \%)$ in a batch rotational contact reactor inoculated with $P$. chrysosporium, containing glucose as co-substrate $\left(5\right.$ g. $\left.\mathrm{L}^{-1}\right)$, treating refined sugar industry effluents. No significant variations of $\mathrm{pH}$ were observed in the experiments. The variations of $\mathrm{pH}$ were of 5.1 to $5.3(\mathrm{CR}), 4.8$ to 5.5 (FR), 5.1 to 6.5 (FBR), 5.1 to 6.2 (FGR), 5.1 to 5.6 (FBGR). The slight increase in $\mathrm{pH}$ could be related with the consumption of organic acids produced from high degradation of organic matter (Rodrigues et al. 2007).

\section{Phase II}

At the end of Phase I, with glucose available to the fungi, removal efficiencies of dye were 97, 83, 76 and $89 \%$ were achieved by the reactors containing no nitrogen source, ammonium chloride (FNIR), ammonium sulphate (FNIIR) and ammonium nitrate (FNIIIR), respectively. These results indicated that the addition of a nitrogen source, in the presence of glucose as co-substrate, was not determinant to achieve good removals of dye, as noted by the velocity constant $\left(k_{2}\right)$ in the reactors with fungi and no nitrogen source (FNNR, Phase I) (Table 2).

Figure 4 gives the results of dye removal during the batch experiments using glucose as cosubstrate.

With the addition of saccharose as co-substrate, the reactors with no nitrogen source (FNNR), ammonium chloride (FNIR), ammonium sulphate (FNIIR) and ammonium nitrate (FNIIIR) achieved $84,90,86$ and $93 \%$ removal of the dye, respectively. Velocity constant $\left(k_{2}\right)$ and correlation coefficient $\left(\mathrm{r}^{2}\right)$ estimated for CR, FNIR, FNIIR, FNIIIR and FNNR reactors in the Phase II are shown in Table 3.

Figure 5 shows the performance of batch reactors on the removal of Congo red dye.

Table 2 - Removals of dye in function of the velocity constant $\left(k_{2}\right)$ and correlation coefficient $\left(\mathrm{r}^{2}\right)$ to $\mathrm{CR}$, FNIR, FNIIR, FNIIIR and FNNR reactors - Phase I.

\begin{tabular}{ccc}
\hline Reactor & $\boldsymbol{k}_{\mathbf{2}}\left(\mathbf{L} \cdot \mathbf{g}^{-1} \cdot \mathbf{d}^{\mathbf{1}}\right)$ & $\mathbf{r}^{\mathbf{2}}$ \\
\hline CR & 2.0 & 0.918 \\
FNIR & 6.0 & 0.911 \\
FNIIR & 12.0 & 0.898 \\
FNIIIR & 7.0 & 0.987 \\
FNNR & 17.0 & 0.946 \\
\hline
\end{tabular}




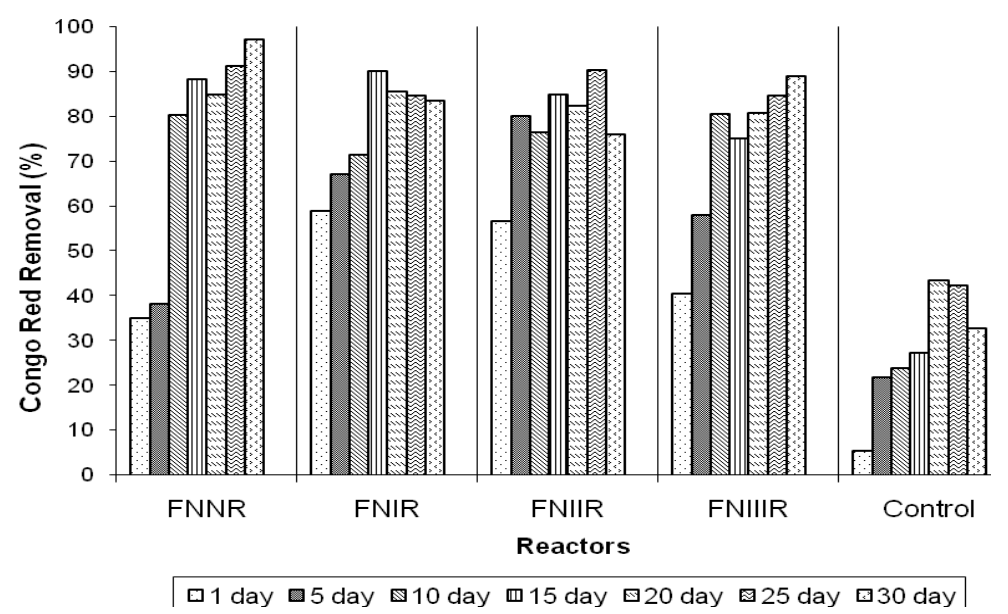

Figure 4 - Performance of the batch reactors with glucose as supplementary carbon source on the removal of congo red dye.

Table 3 - Removals of dye in function of the velocity constant $\left(k_{2}\right)$ and correlation coefficient $\left(\mathrm{r}^{2}\right)$ to CR, FNIR, FNIIR, FNIIIR and FNNR reactors - Phase II.

\begin{tabular}{ccc}
\hline Reactor & $\boldsymbol{k}_{\mathbf{2}}\left(\mathbf{L} \cdot \mathbf{g}^{-1} \cdot \mathbf{d}^{\mathbf{1}}\right)$ & $\mathbf{r}^{\mathbf{2}}$ \\
\hline CR & 2.0 & 0.9177 \\
FNIR & 7.0 & 0.9294 \\
FNIIR & 3.0 & 0.8770 \\
FNIIIR & 16.0 & 0.9519 \\
FNNR & 3.0 & 0.9088 \\
\hline
\end{tabular}

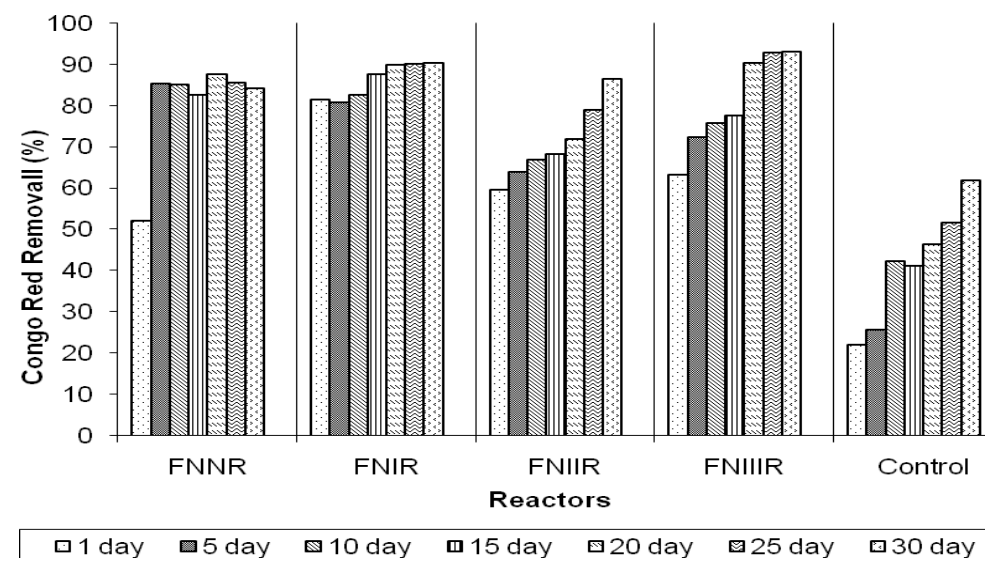

Figure 5 - Performance of the batch reactors with saccharose as a supplementary carbon source on the removal of congo red.

Chen et al. (2008) reported removal of 90 and $97 \%$ of Orange $\mathrm{G}$ dye using glucose as co-substrate and ammonium sulphate as nitrogen source by $P$. sordida and Tyromyces lauteus, respectively. A similar behaviour was noted in this work in the reactors containing ammonium sulphate as nitrogen source (FNIIR) and glucose as cosubstrate that achieved velocity constant $\left(k_{2}\right)$ of 12 $\mathrm{L} \cdot \mathrm{g}^{-1} \cdot \mathrm{d}^{-1}$ and maximum removal of dye of $89 \%$.
Comparing the results obtained in Phase I with glucose to saccharose (Phase II), the best response of the reactors to the removal of dye occurred in the reactors containing glucose and with the absence of nitrogen source, followed by the addition of ammonium sulphate (FNIIR). However, when glucose was substituted by saccharose in the Phase II, reactors containing ammonium nitrate as nitrogen source (FNIIIR) 
presented the highest efficiency of dye removal $(86 \%)$. In the reactor without nitrogen source (RFSN), the presence of glucose as co-substrate (Phase I) increased the velocity coefficient $\left(k_{2}\right)$ of dye removal 5.6 times when compared to the velocity coefficient obtained with the addition of saccharose as co-substrate. The consumption of dye in the presence of saccharose (Phase II) the in reactors with ammonia nitrate (FNIIIR) was 2.3 times higher than that with the addition of glucose as co-substrate. Therefore, it was inferred that glucose increased the efficiency of the culture to consume Congo red dye $\left(17 \mathrm{~L} . \mathrm{g}^{-1} \cdot \mathrm{d}^{-1}\right)$. This velocity was drastically reduced to $3 \mathrm{~L} \cdot \mathrm{g}^{-1} \cdot \mathrm{d}^{-1}$ when glucose was substituted by saccharose as cosubstrate. In Phase II, the addition of a supplementary nitrogen source was necessary to optimize the removal of Congo red dye by the reactors in the presence of saccharose. Since the reactors containing ammonium chloride (FNIR) did not achieve the best response in any phase, this additional source of nitrogen should not be the ideal for $P$. chrysosporium in the studied conditions.

Shahavali et al. (2000) reported that the presence of a nitrogen source contributed to the colour removal of a textile effluent by $P$. chrysosporium in an air-lift bioreactor containing glucose as cosubstrate. However, the application of ammonium chloride as the additional nitrogen source showed minimum effect $(60 \%)$ in the decolourization process. In the present work, the velocity coefficients $\left(k_{2}\right)$ obtained for the reactors (FNIR) containing ammonium chloride as the supplementary source of nitrogen were low, similar to that observed by Shahavali et al. (2000). The use of glucose as co-substrate was better for the removal efficiency (97\%) and velocity constant $\left(17 \mathrm{~L}^{-\mathrm{g}^{-1}} \cdot \mathrm{d}^{-1}\right)$ of the process, as it resulted the best removal of Congo red dye without any source of nitrogen. In the presence of glucose as co-substrate, $\mathrm{pH}$ reduced from 5.0 to 3.8 in FNNR reactors, 5.0 to 3.5 in FNIR and FNIIIR reactors and 5.0 to 4.0 in FNIIR reactors. However, this reduction was more significant in the presence of saccharose, with variations of $\mathrm{pH}$ from 5.0 to 2.1 in FNNR, 5.0 to 2.3 in FNIR, 5.0 to 2.2 in FNIIR and 5.0 to 2.5 in FNIIIR. The minor decrease in the $\mathrm{pH}$ values in the reactors containing glucose was related to the fact that glucose was used for the synthesis of amino acids in comparison to saccharose that was formed by glucose and fructose. In the synthesis of amino acids, the ammonium ion reacts with an intermediary compound from the metabolization of glucose, the $\alpha$-ketoglutarate causing the formation of glutamate. Therefore, with the withdrawn of the ammonium ion, the equilibrium equation of ammonia to ammonium ion tends to the formation of ammonium. This fact generates the consumption of ions $\mathrm{H}^{+}$of the medium and consequently no decrease in the $\mathrm{pH}$ values was observed (Griffin 1994; Motta 2005).

Shahvali et al. (2000) showed the removal of dye by $P$. chrysosporium in an air-lift bioreactor treating textile effluent at $\mathrm{pH}$ of 3.0; however, the authors noted decrease in the decolourization at $\mathrm{pH}$ higher than 5.0 probably due to the osmotic variations in the medium. In the presence of saccharose, the activity of manganese peroxidase enzyme showed a peak common to the reactors at the last day of operation, probably due to the release of intracellular enzymes from the disruption, or fragmentation of hyphae (Colen 2006).

According to the results, higher enzymatic activity occurred in the reactors containing ammonium nitrate (FNIIIR) in the presence of saccharose, confirming the highest value of velocity constant $\left(k_{2}\right)$ of $0.0105 \mu^{-1}{ }^{-1}$.min observed in these reactors at the $5^{\text {th }}$ day of operation. After this, the enzymatic activity reduced during the $10^{\text {th }}$ and $25^{\text {th }}$ days and showed another peak of $0.0613 \mu \mathrm{mol}^{-}$ ${ }^{1}$. min at the $30^{\text {th }}$ day.

\section{CONCLUSIONS}

The results demonstrated the ability of $P$. chrysosporium to remove Congo red dye. The velocity constant $(\mathrm{k} 2)$ of the dye removal was lower in FBR $\left(8 \mathrm{~L} \cdot \mathrm{g}^{-1} \cdot \mathrm{d}^{-1}\right)$ and FBGR $\left(7 \mathrm{~L} \cdot \mathrm{mg}^{-1} \cdot \mathrm{d}^{-1}\right)$ reactors even with the addition of $1 \%(\mathrm{~m} / \mathrm{v})$ wheat bran. However, FR reactors presented satisfactory removal of dye $(77 \%)$, with no necessity of cosubstrate addition, and removal velocity of $12 \mathrm{~L} \cdot \mathrm{g}^{-}$ ${ }^{1} \cdot \mathrm{d}^{-1}$, similar to $14 \mathrm{~L} \cdot \mathrm{g}^{-1} \cdot \mathrm{d}^{-1}$ obtained in the reactors containing glucose. The highest velocity constant of $17 \mathrm{~L} \cdot \mathrm{g}^{-1} \cdot \mathrm{d}^{-1}$ was obtained in the presence of glucose, with the absence of nitrogen source. The results demonstrated that $P$. chrysosporyum could be used for the treatment of textile effluents, considering the nutritional requirements. 


\section{ACKNOWLEDGMENTS}

To the Conselho Nacional de Desenvolvimento Científico e Tecnológico (CNPq) - Edital Jovens Pesquisadores (Process number - 567552-2008).

\section{REFERENCES}

Aguiar Filho JMM. Análise enzimática de fungos lignocelulolíticos cultivados em vinhaça e bagaço de cana de açúcar (MSc. Thesis). São Paulo, Brazil: Escola Superior de Agricultura Luiz de Queiroz; 2008.

Alam MDZ, Mansora MF, Jalal KCA. Optimization of decolorization of methylene blue by lignin peroxidase enzyme produced from sewage sludge with Phanerocheate chrysosporium. Jour Hazard Mater. 2009; 162: 708-715.

APHA. Standard methods for the examination of water and wastewater. 20a. ed. Washington, American Public Health Association, 2003.

Ben Hamman O, La Rubia T, Martinez J. Effect of carbon and nitrogen limitation on lignin peroxidase and manganese peroxidase production by Phanerochaete flavido-alb. Jour of Appl Microbiol. 2003; 83: 751-757.

Binupriya AR, Sathishkumar M, Swaminathan K, Ku CS, Yun SE. Comparative studies on removal of Congo red by native and modified mycelial pellets of Trametes versicolor in various reactor modes. Bioresour Technol. 2008; 99:1080-1088.

Bitton G. Wastewater Microbiology. Third edition, New Jersey: Wiley-Liss Publication; 2005.

Chen C, Chen J, Ni W, Tian X, Huang F. Biodegradation of Orange $\mathrm{G}$ by wood-rot fungi Phanerochaete sordida TXJ-1302A and Tyromyces lauteus TXJ-302B. Bioresour Technol. 2008; 99: 3926-3929.

Chen BY, Lin KW, Wang YM, Yen CY. Revealing interactive toxicity of aromatic amines to azo dye decolorizer Aeromonas hydrophila. J Hazard Mater. 2009; 166: 187-194.

Colen G. Isolamento e seleção de fungos filamentosos produtores de lípases ( $\mathrm{PhD}$, Thesis). Belo Horizonte, Brazil: Faculdade de Farmácia da Universidade Federal de Minas Gerais; 2006.

Damasceno OIC. Remoção de corantes em solução aquosa e efluentes de indústria têxteis por adsorção em cabelo humano (MSc Thesis). Minas Gerais, Brazil: Universidade Federal de Viçosa; 2008.

Dellamatrice PM. Biodegradação e Toxidade de Efluentes Têxteis e Efluentes da Estação de Tratamento de Águas Residuárias de Americana-SP (PhD, Thesis). Piracicaba, Brazil: Escola Superior de Agricultura Luiz de Queiroz; 2005.
Dellamatrice PM, Monteiro RTR, Kamida HM, Nogueira NL, Rossi ML, Blaise C. Decolourization of municipal effluent and sludge by Pleurotus sajorcaju and Pleurotus ostreatus. World J Microbiol Biotechnol. 2005; 21:1363-1369.

Ding J, Cong J, Zhou J, Gao S. Polycyclic aromatic hydrocarbon biodegradation and extracellular enzyme secretion in agitated and stationary cultures of Phanerochaete chrysosporium. J Environ Sci. 2008; 20: 88-93.

Freitas AC, Ferreira F, Costa AM, Pereira R, Antunes SC, Gonçalves F, et al. Biological treatment of the effluent from a bleached kraft pulp mill using basidiomycete and zygomycete fungi. Sci Total Environ. 2009; 407: 3282-3289

Fu Y, Viraraghavan T. Fungal decolourization of dye wastewaters: a review. Bioresour Technol. 2001; 9: 251-62.

Gomma OM, Linz JE, Reddy CA. Decolorization of victoria blue by the white rot fungus Phanerochaete crhysosoporium. J Microbiol Biotechnol. 2008; 24: 2349-2356.

Guimarães C, Porto P, Oliveira R, Mota M. Continuous decolourization of a sugar refinery wastewater in a modified rotating biological contactor with Phanerochate chrysosporium immobilized on polyurethane foam disks. Process Biochem. 2005; 40 : 535-540.

Kamida HM, Durrant LR, Monteiro RTR, Armas ED. Biodegradação de efluente têxtil por Pleurotus sajorcaju. Quim Nova. 2005; 28(4): 629-632.

Mohammadia A, Nasernejad B. Enzymatic degradation of anthracene by the white rot fungus Phanerochaete chrysosporium immobilized on sugarcane bagasse. $J$ Hazard Mater. 2009; 161: 534-537.

Rodrígues S, Fernández M, Bermúdez RC. Tratamiento de efluentes industriales coloreados com Pleurotus spp. Rev Iberoam Micol. 2003; 20: 164-168.

Rodrigues KA, Sampaio GMMS, Zaiat M, Santaella ST. Influência da glicose no consumo de fenol por Aspergillus niger NA 400 de meio sintético em reatores em batelada. Eng Sanit. 2007; 12(2): 222228.

Shahvali M, Assadi MM, Rostami K. Effect of environmental parameters on decolorization of textile wastewater using Phanerochaete chyrosporium. Bioprocess Eng. 2000; 23: 721-726.

Van Der Zee F, Villaverde S. Combined anaerobicaerobic treatment of azo dyes - A short review of bioreactor studies. Water Res. 2000; 39: 1425-1440.

Zanoni MVB, Alves P. O descarte de corantes têxteis. Ciência Hoje. 2001; 29: 61-64. 